\title{
The Effect of Note Taking vs. Summarizing Strategy on Iranian EFL Learners' Listening Comprehension
}

Mehri Khavazi, Mandana Yousefi*, Naeemeh Kharaghan

Department of English Language, Quchan Branch, Islamic Azad University, Quchan, Iran

Corresponding Author: Mandana Yousefi, E-mail: mandanayousefih@gmail.c

\section{ARTICLE INFO}

Article history

Received: November 13, 2017

Accepted: January 10, 2018

Published: March 01, 2018

Volume: 7 Issue: 2

Advance access: February 2018

Conflicts of interest: None

Funding: None

\begin{abstract}
This study, specificall, investigated the effect of note taking and summarizing strategies on Iranian EFL learners' listening comprehension. The study aimed at investigating the effects of note taking and summarizing on listening comprehension of Iranian EFL learners. The participants of the study included 75 female language learners in Bojnord who were homogenized in terms of language proficienc. They were divided into two experimental and onecontrol groups. ANCOVA test was used to analyze the effect of instructing listening strategies on the students' listening comprehension. The results revealed that both note taking and summarizing strategies were effective in enhancing Iranian EFL learners' listening comprehension performance. In addition, it was found that summarizing strategy was more effective than note taking strategy in improving students'listening comprehension. In terms of theoretical implications, the results of the study contribute to the validity of such theories like depth of processing, output hypothesis, and noticing hypothesis.
\end{abstract}

Key words: Note-taking Strategy, Summarizing Strategy, Listening Comprehension

\section{INTRODUCTION}

Listening comprehension is considered to be an important skill in language learning. Language learners want to understand the second language speakers easily and also are interested in the rich variety of aural and visual second language texts available through network media. In addition, listening comprehension is at the center of second language learning and the improvement of second language listening skills can play an important role in improving other language skills (Dunkel, 1988, as cited in Vandergrift, 2007). Therefore, it is essential for learners to improve their listening comprehension; however, they are rarely taught how to listen in second language (Vandergrift, 2007).

Summarizing is a kind of strategy through which students reprocess information and reproduce it in their own words (Jones, 2007). Jones (2007) further maintains that this skill increases learners' comprehension because it needs active reading and listening. In students' words, summarizing is an overview of the main information from reading, listening, or lectures (Tierney \& Shanahan, 1991). A summary is always shorter than the original material and is based on the main ideas (LeBauer, 2000). According to O'Malley and Chamot (1995), note-taking is defined as writing down the essential words and notions in abbreviated verbal, graphic or numerical form, with the aim of facilitating the performance of a language task. Therefore, it can be claimed that summarizing is a useful method in teaching listening to language learners.
To make the role of summarizing more obvious, Fajardo (1996) considered note-taking as a complex activity which combines reading and listening with selecting, summarizing, and writing. Meanwhile, Nwokoreze (1990, p. 42) believed that "it is during the note-taking stage that students reach the highest level of comprehension". As Ayer and Milson (1993) argued, note taking is a well-organized skill that can increase ability to recall and comprehend subject matter. Several studies (Bonner \& Holliday, 2006; Davis \& Hult, 1997; Einstein, 1985) showed its benefits for college students, but little studies have focused on its importance in classes where English is as instructional language and students are non-native English speakers. Accordingly, this study was an attempt to examine the effect of note-taking and summarizing strategies on Iranian learner s' listening comprehension.

In Iran when English language is assumed as a foreign language, there is almost no contact with English users and because of political issues, national television does not broadcast English movies which are in original language. Therefore, there is no exposure to English (Zarei, 2003). On the other hand, the literature shows that these two strategies are effective in helping language learners; however, less attention has been paid to these strategies in Iranian context. Thus, this study was an attempt to find out the effect of employing these two strategies on listening comprehension. Consequently, the researchers aimed to answer the following research questions: 
1) Does note taking strategy have any significant effect on Iranian EFL learners' listening comprehension?

2) Does summarizing strategy have any significant effect on Iranian EFL learners' listening comprehension?

3) Is there any significant difference between note taking and summarizing strategies with regard to Iranian EFL learners' listening comprehension?

\section{REVIEW OF THE RELATED LITERATURE}

According to Chastain (1998), listening is one of the most challenging skills for second language learners. That is to say, many second language learners are criticized because of their incapability of understanding native speakers, real life conversations or speeches, and their performance on reading tasks. Moreover, Hamouda (2013) stated that listening is often perceived by learners as the most difficul L2 skill to learn and can become a source of anxiety for them, which consequently degrades their self-efficacy towards this skill and L2 learning in general. The listeners and readers are exposed to the language by being presented with input flows (Krashen, 1985; Peterson, 2001). Thus, it follows that language learning is by large dependent on the extent to which L2 learners read and listen to the target language.

Accordingly, listening comprehension skill requires research to fi ure out appropriate approaches to its teaching in EFL contexts where exposure to authentic and daily speech is rare. One of the approaches which can possibly help EFL learners improve their listening comprehension is through listening strategies (Gilakjani \& Ahmadi, 2011; Vandergrift \& Tafaghodtari, 2010). Two of the strategies which are likely to assist EFL learners in enhancing listening comprehension performance are note taking and summarizing.

Regarding the complexities associated with the listening comprehension process, empirical studies have identified several factors that make the nature of foreign language listening even more complex (e.g. Goh, 2000; Zhao, 1997). Underwood (1989, as cited in Goh, 2000) determined the following seven challenging areas that may have a negative impact on listening comprehension: having no control over the speed of the spoken language uttered by the speaker, the listening materials are not repeated, vocabulary is limited, sometimes discourse markers are not recognized, listener does not share any contextual knowledge with the speaker, the listener cannot concentrate in a foreign language context, and some established habits such as trying to fi ure out the meaning of every word.

There are numerous studies (e.g. Atay \& Ozbulgan, 2007; Marefat \& Shirazi, 2003; Nemati, 2009; Wei, 2007) in recent years that have noted the effectiveness of using strategies for learning a second language in general. In terms of listening comprehension strategies in the Iranian context of EFL, some studies have been conducted to investigate the effect of strategy instruction on listening comprehension (Birjandi \& Rahimi, 2012; Rasouli, Mollakhan \& Karbalaei, 2013). The results of these studies have revealed that instruction of strategies had a positive effect on listening comprehension of Iranian EFL learners. Moreover, some studies have also been conducted investigating the effect of note taking (e.g. Rahimi \& Sadeghi, 2011) and summarization (e.g. Ghabanchi \& Mirza, 2010) on the reading comprehension performance. However, a review of the previous studies on teaching listening comprehension strategies indicates that, to date, to the best researcher's knowledge, no study has attempted in investigating the effect of note taking and summarizing on the listening comprehension performance of Iranian EFL learners in a single study to compare the effectiveness of these strategies on listening comprehension.

Based on the definition given by Carter and Nunan (2001), listening is a term which language pedagogy uses to refer to a complex process, allowing the listener to fi ure out spoken language. According to Rost (2002), listening is a process the definition of which involves several aspects

Communication would be a daunting endeavor and even an impossible one without listening (Gilakjani \& Ahmadi, 2011). This is because the main channel through which we add up to our learning and insight is listening. "Listening plays an important role in communication as it is said that, of the total time spent on communicating, listening takes up 40-50\%; speaking, $25-30 \%$; reading, $11-16 \%$; and writing, about $9 \%$ "(Gilakjani \& Ahmadi, 2011).

According to what Dunkel (1988) argued, second language learners deal with difficulties recalling what they heard due to their short term memory. Richards and Schmidt (2010) mentioned that during the listening comprehension tasks, teachers take specific notes on questions, main points and responses and provide appropriate hints for students whenever necessary.Note taking is described as the act of keeping the necessary information at hand and feeling relaxed without bearing any tension.

As a higher-level comprehension strategy, summarizing can enhance long-term recall of information, influencing positively individuals' learning. This strategy can be taught by itself or as one of multiple strategies (NRP, 2000; Rinehart, Stahl, \& Erickson, 1986). Instructing learners how to summarize both enhance the quality of their written summaries and considerably influences learners' achievement (Bean \& Steenwyk, 1984; Duke \& Pearson, 2002; Hare \& Borchardt, 1984; McNeil \& Donant, 1982; Taylor, 1982; Taylor \& Beach, 1984).

Summarizing is considered as an important comprehension strategy that can also be used as a method for assessing whether or not learning is taking place. A learner's summary can equip the instructor with valuable information concerning the learner's understanding or lack of understanding. This allows the instructor to provide the learner with additional required instruction. Besides, summarizing can also help the learners in self-assessing their own learning. In fact, teaching summarization plays a crucial role in today's assessment methods (Kamil, 2004).

Today, listening comprehension serves as a crucial skill in L2 learning. In fact, L2 learners are eager to understand and comprehend the L2 speakers easily, being interested in the rich variety of aural and visual L2 texts available through network media (Dunkel, 1988, as cited in Vandergrift, 2007). In addition, listening comprehension is one of the pivotal skills in L2 learning, with the development of L2 listening 
skill playing an essential role in enhancing other language skills (Dunkel, 1988, as cited in Vandergrift, 2007).

As a strategy of this kind, summarizing is considered as a skill thereby learners reprocess information and reconstruct it, using their own words. This skill enhances learners' comprehension since it requires active reading and listening. In learners' words, summarizing presents an overview of the main information from reading, listening, or lectures (LeBauer, 2000). Note - taking is considered as another strategy. Ayer and Milson (1993) maintain that as a well-organized skill, note-taking can enhance one's ability to recall and understand subject matter. Many studies (e.g. Bonner \& Holliday, 2006; Davis \& Hult, 1997; Einstein, 1985) have revealed its benefits for college students

Highlighting the importance of strategy instruction for listening, Vandergrift and Tafaghodtari (2010) notes that since being able to understand the spoken input requires the listener to simultaneously process various kinds of information, the EFL learners are in need of using strategies to improve their listening comprehension. According to Vandergrift (1999), comprehending the language entails the coordination of sounds, lexical items, grammatical structures, and real world knowledge. Thus, many researchers including Vogely (1999) and Gonen (2009) believe in the complex nature of listening. Regarding the complexities associated with the listening comprehension process, empirical studies have identified several factors that make the nature of foreign language listening even more complex (e.g. Goh, 2000; Zhao, 1997). Underwood (1989, as cited in Goh, 2000) determined the following seven challenging areas that may have a negative impact on listening comprehension: having no control over the speed of the spoken language uttered by the speaker, the listening materials are not repeated, vocabulary is limited, sometimes discourse markers are not recognized, listener does not share any contextual knowledge with the speaker, the listener cannot concentrate in a foreign language context, and some established habits such as trying to fi ure out the meaning of every word. Thus, in order to address the above-mentioned problems associated with the complex and demanding nature of listening comprehension process and fill the gap in the literature, the current study sought to explore whether note taking and summarizing can help Iranian EFL learners to develop their listening comprehension.

Accordingly, there were three purposes for this study: First, it was examined if note taking strategy had any significant effect on learners' listening comprehension. Second, it was investigated if summarization strategy had any significant effect on learners' listening comprehension. Third, the study attempted to fi ure out which of the two strategies (note taking or summarization) was more effective in improving the listening comprehension of EFL learners.

\section{METHODOLOGY}

\section{Participants}

A total number of 75 female students, studying English as a foreign language (EFL) in a language institute of Bojnourd, Iran, participated in this study. The sampling was done based on purposive sampling method. Their age range was from 13 to 18 . No information was available regarding the socio-economic status of the students or their educational achievement records. The sample was homogenized in terms of language proficiency based on the obtained information from Preliminary English Test (PET) results. These students were divided into three groups of 25 representing two experimental groups and one control group.

\section{Instrumentation}

As mentioned earlier, the PET language proficiency test was administered to homogenizethe sample. Preliminary English Test (PET) is a qualification in English as a Foreign Language awarded by Cambridge ESOL. The test has these sections:

A- Reading Writingare taken together - 90 minutes

B- Listening - 30 minutes

C- Speaking - an interview, 10 minutes

A sample of Preliminary English Test was extracted from Preliminary English Test 5 of Cambridge ESOL Examinations published by Cambridge University Press (PET, 2011).

\section{Pretest and posttest}

The listening section of PET was utilized as the listening comprehension measure. It was served as the pretest and posttest of the study to detect the effect of treatment (summarizing and note taking) on listening comprehension of the participants of the study. It consists of four sections; part one has 7 multiple choice questions ( 7 points), part two includes 6 multiple choice questions ( 6 points), part three has six fill in the blanks questions ( 6 points), and part four involves 5 yes/ no questions (5 points). The internal consistency of listening test was measured as 0.81 using Cronbach's Alpha measure of reliability after piloting it on 20 language learners.

\section{Procedure}

At first 75 students were selected and divided into three equal groups. One experimental group served as the group practicing summarizing, another experimental group practicing note taking, and the last one as the control group. In addition, to make sure that groups were homogeneous in terms of listening proficienc, their listening scores were extracted from their total PET scores and it was confirmed that the three groups were homogeneous with regard to their listening ability. Then, the experimentation started as follows:

In the group receiving summarizing strategy, students were taught how to summarize a listening recording based on the procedure proposed by Day (1980). The listening recordings used for instruction in the current study included a collection of 20 listening recordings from samples of previous PETs. Based on the length of these recordings, care was taken to select listening recordings of various lengths to make the collection as representative as possible of listening recordings used in these tests. Accordingly, 7 short recordings, 7 of medium length, and 6 long ones were chosen to be used as the instructional materials. The short recordings had 
a duration of less than 1 minute, medium length recordings had a duration of approximately 2 minutes, and long ones had a duration of approximately 4 minutes. Day's summary guidelines include collapse list, use topic sentences, get rid of unnecessary details, and collapse paragraph. In the collapse list rule, students should notice the list of things they hear while listening and label them as one thing. For instance, when they hear words like pan, spoon, pot, forks, they can think of them as kitchen tools instead of memorizing all the items. In the rule use topic sentences, thelistener should pay attention to the topic sentence in the recordings. Topic sentence bears the most important information of a peace of text and it regularly appears at the beginning or the end of the text. In case there is no such topic sentence, the listener should make up one based on the information in the recording. With regard to rule of getting rid of unnecessary details, listeners need to know that some information in a recording are unnecessary, repetitive and trivial and can be simply ignored. Such trivial information can be background speeches and things that are repeated by the speaker in various ways.

Finally, in the rule collapse paragraph which is mainly related to summarizing written texts, students should be aware that certain paragraphs in a written text just provide redundant information and further explanations and they can ignore such paragraphs in their summary. To make this rule compatible with listening activities, students were informed that certain parts of recording included extra information and explanations and they didn't need to include them in their summary. For instance, when a speaker talks about prices of apartments in big cities he or she may go at length and talk about kinds of housing and apartments that are not directly related to the topic of the speech. Students in summarizing group were taught how to use the guidelines to summarize listening recordings in one session and in another session they practiced summarizing listening recordings using all the guidelines at once. In the following 10 sessions of 90 minutes, students first summarized the recordings and then they listened to the recording for another time to review their summary and finally they checked their comprehension with the instructor.

In note taking group, students received instruction on how to take notes while listening to a piece of recording. This instruction was performed by giving instructional handouts on note taking to the students. A handout containing good practices of note taking was also used in the study. This handout has been developed by Carrell (2007) in order to instruct language learners how to take notes when listening. Carrell (2007) has claimed that this handout has been developed based on literature on effective note taking strategies and can be used to learn note taking strategies without the help of any instructors (See Appendix A). These handouts were distributed among the participants and they were asked to study them independently and get prepared for the next session. In the next session, all the items of the handout were reviewed with instructor to make sure that students had learned the content of the handouts. From that session on, the students were asked to use note taking tips stipulated in the handouts while listening to the recordings (see appendix B for lesson plan). Recordings played twice; once for students to listen and take notes and one more time to listen and review their notes. Afterward, students checked their comprehension and notes with the help of instructor. The instruction period lasted for 10 sessions of 90 minutes.

In the control group, the students did not receive any instruction about summarizing and note taking and just listened to the recordings two times and checked their comprehension with the instructor through questioning and receiving explaining.

After the instruction sessions were over, students sat for the same listening test of PET they took at the beginning of the experimentation. Scores obtained from this test were analyzed to find the answer to each research question

\section{DATA ANALYSIS}

\section{Homogeneity of Participant on Language Proficiency}

In the first step, it was needed to choose participants with homogeneous language proficiency to remove any threats due to the possible effect of language proficienc . As stated earlier, PET was used for this purpose and Table 4.1 shows the descriptive statistics for the three groups of the study.

As seen in Table 4.1, the summarizing group had a mean score of $51.84(\mathrm{SD}=3.54)$, the note taking group had a mean score of $51.36(\mathrm{SD}=3.12)$, and the control group had a mean score of $51.72(\mathrm{SD}=3.69)$. In addition, the result of Kolmogorov Smirnov test of normality indicated that significant levels of PET scores in all the groups are greater than confidence interval of 0.05 which means than all PET scores are normally distributed. Though the three groups had similar mean scores, ANOVA was run among the groups to further make sure they are not significantly different from each other or in other words they are homogeneous in terms of language proficienc. Table 4.2 presents the ANOVA results.

According to the results of Levene's test of equality of variances, all the groups had equal variances in PET scores $(p>0.05)$ which secured the use of ANOVA. The significant level of ANOVA was greater than the confidence interval of 0.05 indicating no significant differences between the groups in terms of general language proficienc .

\section{Analysis of the Effect of Note-taking on Iranian EFL Learners' Listening Comprehension}

The first research question was to find the significant effect of note taking strategy on Iranian EFL learners' listening comprehension. To this aim, an ANCOVA was used.

Tabachnick and Fidell (2007) mentioned equal sample sizes, outliers, multicollinearity, normality, homogeneity of variance, linearity, and homogeneity of regression as the ANCOVA assumptions which needs to be checked before running ANCOVA. As for the equal sample size, the present study included three groups of equal sample size and accordingly this assumption was already met. With respect of normality of data, Kolmogorov Smirnov test of normality was run on the pretest and posttest of note taking and control groups, the result of which is presented in the following Table. 
Table 4.1. Descriptive statistics of PET for summarization group, Note taking group, and control group

\begin{tabular}{lccccccccc}
\hline & N & Mean & $\begin{array}{c}\text { Standard } \\
\text { deviation }\end{array}$ & $\begin{array}{c}\text { Standard } \\
\text { error }\end{array}$ & Minimum & Maximum & \multicolumn{3}{c}{ Kolmogorov-Smirnova } \\
\cline { 7 - 10 } & & & & & Statistic & df & Sig. \\
\hline Note taking & 25 & 51.3600 & 3.12090 & 0.62418 & 45.00 & 57.00 & 0.140 & 25 & $0.200^{*}$ \\
Summarization & 25 & 51.8400 & 3.54354 & 0.70871 & 45.00 & 58.00 & 0.148 & 25 & 0.162 \\
Control & 25 & 51.7200 & 3.69143 & 0.73829 & 43.00 & 60.00 & 0.116 & 25 & $0.200^{*}$ \\
Total & 75 & 51.6400 & 3.41950 & 0.39485 & 43.00 & 60.00 & & \\
\hline
\end{tabular}

Table 4.2. Result of ANOVA and test of levene between summarization group, Note taking group, and control group on PET scores

\begin{tabular}{|c|c|c|c|c|c|c|c|c|c|}
\hline & Sum of squares & df & Mean square & $\mathbf{F}$ & Sig. & Levene statistic & df1 & df2 & Sig. \\
\hline Between groups & 0.156 & 2 & 0.078 & 0.008 & 0.992 & 0.346 & 2 & 71 & 0.708 \\
\hline Within groups & 670.438 & 71 & 9.443 & & & & & & \\
\hline Total & 670.595 & 73 & & & & & & & \\
\hline
\end{tabular}

As Table 4.3 shows, the significant levels of listening pretest and posttest scores both in note taking and control groups are greater than confidence interval of 0.05 indicating normal distribution of data. To make sure that the data related to posttest and pretest in control and note taking groups are free from any outliers, boxplots of the data sets were checked.

As the Figure 4.1 shows, case number 13 was an outlier in pretest of note taking group and accordingly this case was removed from the data sets related to listening pretest but no cases were indicated as the outliers in the data sets related to listening posttest test. To check the multicollinearity assumption, it must be shown that strong correlation does not exist between the covariates (Pallant, 2010). Since in this analysis there was only one covariate (pretest), it automatically removed any concerns regarding multicollinearity. Linearity assumption refers to the existence of a linear relationship among dependent variable and covariates (Pallant, 2010). This assumption can be examined using scatterplot. Figures 4.2 shows the relationship between dependent variable and covariate for control and note taking groups.

Figure 4.2 scatterplot showing the relationship between pretest (covariate) and posttest (dependent variable)

The relationship between dependent variable and covariate is in the form of straight diagonal lines that signals the linearity of relationships, and accordingly, linearity assumption is met (Pallant, 2010). Moreover, the two lines in each scatterplot representing each group of the study are in a way that shows similar slopes. This similarity of slope indicates that the relationship between the covariate and the dependent variable is homogeneous in terms of regression slopes (Pallant, 2010). In addition, through customizing univariate model and setting the interaction model, assumption of homogeneity of regression slopes was further examined. Table 4.5 shows the results of interaction model.

Table 4.4 shows that significant level in the row labeled Groups * Listening Pretest is 0.65 which is greater than the confidence interval of 0.05 . Therefore, there is no significant interaction and assumption of homogeneity of regression slopes is met for the scores related to listening test.
Table 4.3. Result of Kolmogorov Smirnov tests of normality

\begin{tabular}{llccc}
\hline & Groups & \multicolumn{3}{c}{ Kolmogorov-Smirnova } \\
\cline { 3 - 5 } & & Statistic & df & Sig. \\
\hline Listening Pretest & Note taking & 0.113 & 24 & $0.200^{*}$ \\
& Control & 0.094 & 25 & $0.200^{*}$ \\
Listening Posttest & Note taking & 0.100 & 24 & $0.200^{*}$ \\
& Control & 0.156 & 25 & 0.119 \\
\hline
\end{tabular}

The last assumption is the equality of variances which was examined through Levene's test of equality of error variances. Table 4.5 shows the results of Levene's test.

As the Table shows, the significant value is greater than the confidence interval of 0.05 indicating the equal variances across the groups in listening scores. Therefore, the assumption of equality of variances was also met.

Now to probe the first null hypothesis of the present study as note taking does not significantly affect the learners' listening comprehension, a one-way ANCOVA was run. Tables 4.6 displays the results.

As Table 4.6 shows, the level of significance is 0.00 which is lower than the confidence value of 0.05 indicating that the difference between the posttest scores of the two groups is statistically significant. The effect size is 0.24 which based on Cohen (1988) is considered a large effect size. Therefore, it can be concluded that the null hypothesis of the present study is rejected and there is a significant effect of note taking strategy on Iranian learners' listening comprehension.

\section{Analysis of the Effect of Summarizing on Iranian EFL Learners' Listening Comprehension}

The second research question of the study tried to investigate any significant effect of summarizing strategy on Iranian EFL learners' listening comprehension. Thus, another ANCOVA was conducted and the required assumptions were checked. Tables 4.7 displays the results.

As the above Table shows, the level of significance is 0.00 which is lower than the confidence value of 0.05 
Table 4.4. Tests of between-subjects effects to examine the assumption of homogeneity of regression slopes for scores of listening

\begin{tabular}{|c|c|c|c|c|c|}
\hline Source & Type III sum of squares & df & Mean square & $\mathbf{F}$ & Sig. \\
\hline Corrected model & $413.369 \mathrm{a}$ & 3 & 137.790 & 165.578 & 0.000 \\
\hline Intercept & 2.894 & 1 & 2.894 & 3.478 & 0.069 \\
\hline Group 2 & 1.279 & 1 & 1.279 & 1.537 & 0.221 \\
\hline Listening Pretest & 387.365 & 1 & 387.365 & 465.488 & 0.000 \\
\hline Group $2 *$ Listening Pretest & 0.148 & 1 & 0.148 & 0.178 & 0.675 \\
\hline Error & 37.448 & 45 & 0.832 & & \\
\hline Total & 9971.000 & 49 & & & \\
\hline Corrected total & 450.816 & 48 & & & \\
\hline
\end{tabular}

a. $\mathrm{R}$ squared $=0.917$ (Adjusted $\mathrm{R}$ squared $=0.911$ )

Table 4.5. Levene's test of equality of error variances

\begin{tabular}{lccc}
\hline F & df1 & df2 & Sig. \\
\hline 0.504 & 1 & 47 & 0.481 \\
\hline
\end{tabular}

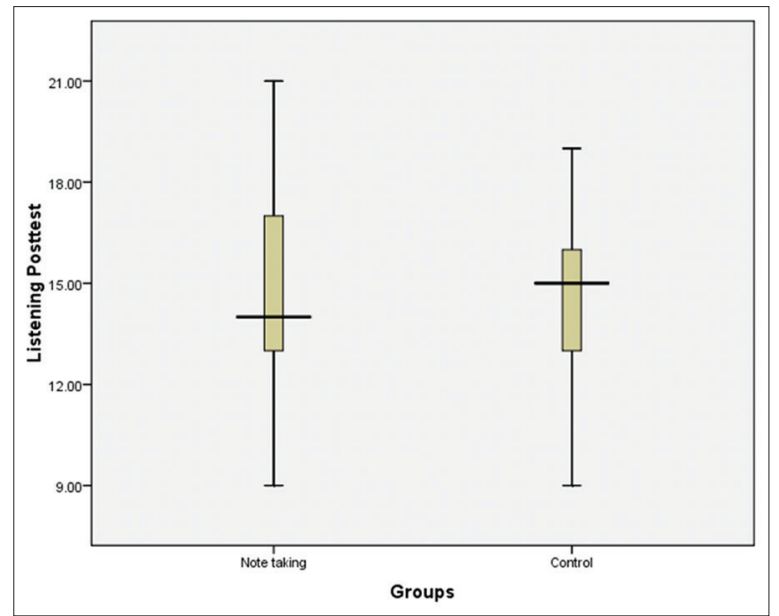

Figure 4.1. Boxplot for control and note taking groups in posttest

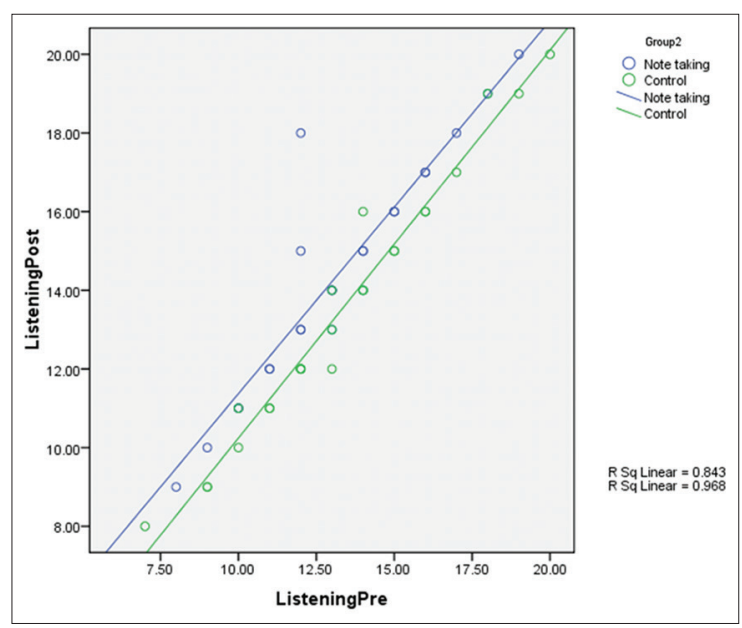

Figure 4.2. Scatterplot showing the relationship between pretest (covariate) and posttest (dependent variable)

indicating that the difference between the posttest scores of the two groups is statistically significant. The effect size is
0.82, which based on Cohen (1988), is considered a large effect size. There was also a significant relationship between the covariate (pretest) and the dependent variable (posttest) as indicated by Partial Eta Squared value of 0.89 . Therefore, it can be concluded that the null hypothesis of the present study was rejected and there was a significant effect of summarization strategy on Iranian learners' listening comprehension.

\section{Analysis of Significant Difference between Note Taking and Summarizing Strategies}

The third research question was about any significant differences between note taking and summarizing on Iranian EFL learners' listening comprehension. Independent samples t-test was run on posttest scores to find the answer to the third research question. Table 4.8 shows the result of independent samples t-test.

As the Table shows, the level of significance is 0.002 which is lower than the confidence value of 0.05 indicating that the difference between the posttest scores of the two groups is statistically significant. Therefore, the null hypothesis of the present study was rejected and there was a significant difference between summarization strategy and note taking strategy in terms of affecting Iranian learners' listening comprehension.

\section{DISCUSSION AND CONCLUSION}

The purpose of the study was to explore the effect of summarization strategy and note taking strategy on listening comprehension of Iranian EFL learners. The study adopted a quasi-experimental design. The first null hypothesis was that note taking strategy did not have significant effect on EFL learners' listening comprehension. However, the results of ANCOVA indicated that the difference between the control and experimental (note taking group) groups was statistically significant, and note taking group outperformed the control group and the null hypothesis was rejected. Consistent with finding of the present study, Ehrman and Oxford (1988) found that the higher the students level of proficiency in speaking, reading, and listening skills, the more frequently they chose to use learning strategies. In the realm of L2 listening strategies 
Table 4.6. Results of ANCOVA on pretest and posttest scores of control and note taking groups

\begin{tabular}{lcccccc}
\hline Source & Type III sum of squares & df & Mean square & F & Sig. & Partial Eta squared \\
\hline Corrected model & $413.221 \mathrm{a}$ & 2 & 206.610 & 252.796 & 0.000 & 0.917 \\
Intercept & 2.756 & 1 & 2.756 & 3.372 & 0.073 & 0.068 \\
Listening pretest & 402.478 & 1 & 402.478 & 492.448 & 0.000 & 0.915 \\
Group & 12.396 & 1 & 12.396 & 15.168 & 0.000 & 0.248 \\
Error & 37.596 & 46 & 0.817 & & & \\
Total & 9971.000 & 49 & & & & \\
Corrected total & 450.816 & 48 & & & & \\
\hline
\end{tabular}

a. $\mathrm{R}$ squared $=0.917$ (Adjusted $\mathrm{R}$ squared $=0.913$ )

Table 4.7. Results of ANCOVA on the posttest scores of control and summarization groups

\begin{tabular}{lcccccc}
\hline Source & Type III sum of squares & df & Mean square & F & Sig. & Partial Eta squared \\
\hline Corrected model & $559.648 \mathrm{a}$ & 2 & 279.824 & 292.646 & 0.000 & 0.927 \\
Intercept & 28.476 & 1 & 28.476 & 29.781 & 0.000 & 0.393 \\
Listening pretest & 373.880 & 1 & 373.880 & 391.013 & 0.000 & 0.895 \\
Group & 206.796 & 1 & 206.796 & 216.272 & 0.000 & 0.825 \\
Error & 43.985 & 46 & 0.956 & & & \\
Total & 12206.000 & 49 & & & & \\
Corrected total & 603.633 & 48 & & & & \\
\hline
\end{tabular}

a. $\mathrm{R}$ squared $=0.927$ (Adjusted $\mathrm{R}$ squared $=0.924)$

Table 4.8. Result of independent samples T-test

\begin{tabular}{|c|c|c|c|c|c|c|c|}
\hline & \multicolumn{2}{|c|}{$\begin{array}{l}\text { Levene's test } \\
\text { for equality of } \\
\text { variances }\end{array}$} & \multicolumn{5}{|c|}{ t-test for equality of means } \\
\hline & $\mathbf{F}$ & Sig. & $\mathbf{t}$ & df & Sig. (2-tailed) & $\begin{array}{c}\text { Mean } \\
\text { difference }\end{array}$ & $\begin{array}{c}\text { Standard error } \\
\text { difference }\end{array}$ \\
\hline \multicolumn{8}{|l|}{ Listening Posttest } \\
\hline Equal variances assumed & 0.640 & 0.428 & -3.253 & 47 & 0.002 & -2.69500 & 0.82853 \\
\hline Equal variances not assumed & & & -3.262 & 46.540 & 0.002 & -2.69500 & 0.82610 \\
\hline
\end{tabular}

and listening comprehension studies by O'Malley, Chamot, and Kupper, (1989), Vandergrift (1997), Goh (2002), Vandergrift (2003) and Liu (2008) also point to the more effective strategy use by more proficient L2 listeners

With regard to the positive effect of note taking strategy, the finding of the present study is in line with studies by Bonner and Holliday (2006), Davis and Hult (1997), and Einstein (1985). The finding of present study is also in line with the theory of depth of processing. The extra cognitive load involved in note taking while listening can contribute to depth of processing and deeper learning too. Moreover, the finding of present study is also confirmed by noticing hypothesis by Schmidt (1990) because note-taking allows the learners to pay more attention to essential points and to devote less attention to trivial details (Robinson et.al, 2006). With respect to the association of present study with other empirical studies, the present study is in agreement with the study by Rahimi and Sadeghi (2011). They studied effects of note-taking strategy training on comprehension and retention of Iranian EFL learner and they found out that the experimental group outperformed the control group on both comprehension and recall tests. Accordingly it can be inferred that the present study adds positively to the already existing literature on note taking strategy and listening comprehension.

The second null hypothesis was that the summarizing strategy does not have any significant effect on EFL learners' listening comprehension. Again, the results of the ANCOVA indicated that the difference between the posttest scores of the control and experimental summarizing groups was statistically significant, and accordingly, summarizing group outperformed the control group and the second null hypothesis was rejected too. This finding is in line with studies by O'Malley, Chamot, and Kupper, (1989), Vandergrift (1997), Goh (2002), Vandergrift (2003) and Liu (2008). In addition, through summarizing, learners reprocess information and reconstruct it, using their own words. This active reconstruction of meaning by learners would add to the depth 
of processing and deeper learning. Depth of processing is referred to the extent of cognitive effort, analysis, process of intake and use of previous knowledge, creating and attesting hypothesis for encoding and decoding of input (Leow 2015). In this regard, Morgan-Short et al. (2012) found a significant positive relationship between depth of processing and comprehension score of 308 students.

The final null hypothesis was that no significant difference was between note taking strategy and summarizing strategy with regard to learners' listening comprehension. This hypothesis was also rejected and the results indicated that there was a significant difference between the two groups. Although both note taking and summarizing strategies were found positive in enhancing L2 listening performance of Iranian EFL learners while summarizing strategy was more effective on listening comprehension. This finding should not be considered as conclusive and because randomization was not employed in this study, the findings are of limited generalizability. However, there are several explanations to support the superiority of summarizing group. First of all, summarization needs more elaboration and recoding to convert the content of message to more succinct and informative message. In other words, language learners need to listen to a text, comprehend it, identify the main ideas, and reword it using their own words. In addition, summarization is considered as generative strategy (Grabowski, 2004). The generative learning theory postulates that learners develop associations between new information and their previous knowledge. This characterization of generative strategy is also in line with constructivism theory of learning which assumes that learning is a unique experience and individuals' understanding is shaped by his past experiences and relating them to the new information (Bruner, 1996). In addition, summarizing strategy can be seen as an output based activity in which language learners need to produce language rather than just receive the language. Output hypothesis was put forward by Swain (1995, 2000, and 2005). Swain (1995) states that being involved with output or meaning expression leads to better attention and focus on the target language and mere input is insufficient for developing language system

In sum, note taking is a fruitful strategy in listening comprehension and the extra cognitive tasks involved in note taking contribute to depth of processing and deeper learning too. It was also argued that note-taking allow the learners to pay more attention to essential points which might have led to enhancement of listening comprehension. Meanwhile, summarizing can be an effective tool in helping students improve their listening comprehension. It was also concluded that the active reconstruction of meaning by learners through summarizing might have led to the depth of processing and deeper learning. Finally, it was concluded that Iranian EFL learners might benefit more from summarizing strategy rather than note taking strategy for developing listening proficiency. It was concluded that several attributes of summarizing strategy might have been responsible for its better effect on listening comprehension. These attributes were more elaboration and recoding needed for summarizing and the generative nature of summarizing which connected it to the output hypothesis.

\section{REFERENCES}

Atay, D., \& Ozbulgan, C. (2007). Memory strategy instruction, contextual learning and ESP vocabulary recall. English for specific purposes. 2 (1), 39-51.

Ayer, W. W., \& Milson, J. L. (1993). The effect of note taking and underlining on achievement in middle school life science. Journal of Instructional Psychology, 20 (2), 91-95.

Bean, T., \& Steenwyk, F. (1984). The effect of three forms of summarization instruction on sixth graders' summary writing and comprehension. Journal of Reading Behavior, 16 (3), 297 - 306.

Birjandi, P., \& Rahimi, A. H. (2012). The effect of metacognitive strategy instruction on the listening performance of EFL students. International Journal of Linguistics, 4 (2), 495-517.

Bonner, J. M., \& Holliday, W. G. (2006). How college science students engage in note-taking strategies. Journal of Research in Science Teaching, 43(8), 786-818.

Bruner, J. (1996). The Culture of Education, Cambridge, MA: Harvard University Press.

Carrell, P. L. (2007). Note taking strategies and their relationship to performance on listening comprehension and communicative assessment tasks (TOEFL Monograph Series No. RS-35). Princeton, New Jersey: ETS. Retrieved January 24, 2016, from https://www.ets.org/ Media/Research/pdf/RR-07-01.pdf

Carter, R., \& Nunan, D. (2001). The Cambridge guide to teaching English to speakers of other languages. Cambridge: CUP.

Chamot, A. U. (1995). Learning strategies and listening comprehension. In D. Mendelsohn \& J. Rubin (Eds.). A Guide for the Teaching of Second Listening. (pp. 1330). San Diego, California: Dominie Press.

Chastain, K. (1988/1998). Developing second language skills: Theory and practice $\left(3^{\text {rd }} \mathrm{ed}\right)$. Boston: Harcourt Inc.

Cohen, J. (1992). A power primer. Psychological bulletin, $112(1), 155$.

Davis, M., \& Hult, R. E. (1997). Effects of writing summaries as a generative learning activity during note-taking. Teaching of Psychology, 24 (1), 47-49.

Day, J. D. (1980). Training summarization skills: A comparison of teaching methods. Unpublished doctoral dissertation, University of Illinois.

Duke, N., \& Pearson, P. D. (2002). Effective practices for developing reading comprehension. In A.E. Farstrup \& S.J. Samuels (Eds.), What research has to say about reading instruction ( $3^{\text {rd }}$ ed., pp. $205-242$ ). Newark, DE: International Reading Association.

Dunkel, P. (1988). The content of L1 and L2 students' lecture notes and its relation to test performance. TESOL Quarterly, 2(2), 259-281.

Ehrman, M., \& Oxford, R. (1988). Ants and grasshoppers, badgers and butterflies: Qualitative and quantitative exploration of adult language learning styles and strategies. Paper presented at the Symposium on Research Perspectives on Adult Language Learning and Acquisition, Ohio State University, Columbus, $\mathrm{OH}$. 
Einstein, G. O. (1985). Note-taking, Individual Differences, and Memory for Lecture Information. Journal of Educational Psychology, 77(5), 522-532.

Fajardo, C. P. (1996). Note-taking: A useful device. English Teaching Forum 34(2), 22-26.

Ghabanchi, Z., \& Haji-Mirza, F. (2010). The effect of summarization on intermediate EFL learners' reading comprehension and their performance on display, referential and inferential questions. Journal of College Teaching and Learning, 7(9), 53-60.

Gilakjani, P. A., \& Ahmadi, M. (2011). A Study of Factors Affecting EFL Learners' English Listening Comprehension and the Strategies for Improvement. Journal of Language Teaching and Research, 2 (5), 977-988.

Goh, C. (2000). A cognitive perspective on language learners' listening comprehension problems. System, 28(1), 55-57.

Goh, C. (2002). Exploring listening comprehension tactics and their interaction patterns. System, 30 (2), 185-206.

Grabowski, B. L. (2004). Generative learning contributions to the design of instruction and learning. In Handbook of Research on Educational Communications and Technology, $2^{\text {nd }}$ ed., edited by D. H. Jonassen and Association for Edu-cational Communications and Technology, (pp. 719-743). Mahwah, New Jersey: Lawrence Erlbaum Associates.

Hamouda, A. (2013). An Investigation of Listening Comprehension Problems Encountered by Saudi Students in the EL Listening Classroom. International Journal of Academic Research in Progressive Education and Development, 2 (2), 113-15.

Hare, V., \& Borchardt, K. (1984). Direct instruction of summarization skills. Reading Research Quarterly, 20 (1), $62-78$.

Jones, L. (2007). The Student Centered Classroom. New York: Cambridge University Press. Retrieved January 25, 2016, from http://www.cambridge.org/other files/downloads/esl/booklets/Jones-Student-Centered pdf.

Jones, L. (2007). The student-centered Classroom. New York: Cambridge University Press Alexandria Virginia.

Kamil, M. L. (2004). Vocabulary and comprehension instruction: Summary and implications of the National Reading Panel findings. In P. McCardle and V. Chhabra (Eds.), The voice of evidence in reading research. Baltimore, (pp. 172-185). MD: Paul H. Brookes.

Krashen, S. (1985). The input hypothesis. Beverly Hills: Laredo.

LeBauer, R. S. (2000). Learn to listen: Listen to learn. Academic listening and note-taking ( $2^{\text {nd }}$ Ed.). New York: Longman.

Leow, R. P. (2015). Explicit Learning in the L2 Classroom: A Student-Centered Approach. London and New York: Routledge.

Liu, H. J. (2008). A study of the interrelationship between listening strategy use, listening proficiency levels, and learning style. RARECLS, 5(1), 84-104.

Marefat, H., \& Shirazi, M. A. (2003). The Impact of Teaching Direct Learning Strategies on the Retention of Vo- cabulary by EFL Learners. The Reading Matrix, 3(2), 47-62.

McNeil, J., \& Donant, L. (1982). Summarization strategy for improving reading comprehension. In J. A. Niles \& L. A. Harris (Eds.), New inquiries in reading research and instruction (pp. 215 - 219). Rochester, NY: National Reading Conference.

Morgan-Short, K., Heil, J., Botero-Moriarty, A., \& Ebert, S. (2012). Allocation of attention to second language form and meaning. Studies in Second Language Acquisition, 34(4), 659-685.

National Reading Panel (2000). Teaching children to read: An evidence-based assessment of scientific research literature on reading and its implications for reading instruction. Bethesda, MD: National Institutes of Health.

Nemati, A. (2009). Memory vocabulary learning strategies and long-term retention. International Journal of Vocational and Technical Education, 1 (2), 14-24.

Nwokoreze, U. N. D. (1990). Note-taking. English Teaching Forum, 33(2), 39-40.

O’Malley, J. M., Chamot, A. U., \& Küpper, L. (1989). Listening comprehension strategies in second language acquisition. Applied Linguistics, 10(4), 418-437.

Pallant, J. S. (2010). SPSS Survival Manual, A Step by Step Guide to Data Analysis using SPSS for Windows. ( $4^{\text {th }}$ ed.). Allen \& Unwin, Crows Nest.

Peterson, P. (2001). Skills and strategies for proficient listening. In M. Celce-Murcia (Ed.), Teaching English as a second or foreign language. Boston: Heinle \& Heinle.

Rahimi, M., Sadighi, F., \& Hosseinyfard, Z. (2011). The impact of linguistic and emotional intelligence on the reading performance of Iranian EFL learners. The Journal of Teaching Language Skills, 3(1), 151-171.

Rasouli, M., Mollakhan, K., \& Karbalaei, A. (2013). The effect of metacognitive listening strategy training on listening comprehension in Iranian EFL context. European Online Journal of Natural and Social Sciences, 2(1), $115-128$

Rinehart, S., Stahl, S., \& Erickson, L. (1986). Some effects of summarizing training on reading and studying. Reading Research Quarterly, 21(5), 422 - 438.

Robinson, D. H., Katayama, A. D., Odom, S., Beth, A., Hsieh, Y. P., \& Vanderveen, A. (2006). Increasing text comprehension and graphic note-taking using a partial graphic organizer task. Journal of Educational Research, 100(1), 103-111.

Rost, M. (2002). Teaching and Researching Listening. London, United Kingdom: Longman.

Tierney, R. J., \& Shanahan, T. (1991). Research on the reading-writing relationship: Interactions, transactions, and outcomes. In R Barr, P.D. Pearson, P.B. Mosenthal \& M.L. Kamil (Eds.), Handbook of Reading Research., 2(3), (pp. 246-279). White Plains, New York: Longman.

Schmidt-Reinhart, B. (1994). The effects of topic familiarity on second language listening comprehension. Modern Language Journal, 78(2), 179-189.

Swain, M. (1995). Three functions of output in second language learning. In G. Cook \& B. Seidlhofer (Eds.), Prin- 
ciple and practice in applied linguistics: Studies in honor of H. G. Widdowson (pp. 125-144). Oxford: Oxford University Press.

Swain, M. (2000). The output hypothesis and beyond: Mediating acquisition through collaborative dialogue. In J. Lantolf(Ed.), Sociocultural theory and second language learning (pp. 97-114). Oxford: Oxford University Press.

Swain, M. (2005). The output hypothesis: theory and research. In E. Hinkel (Eds.). Handbook of Research in Second Language Teaching and Learning (pp. 471483). Mahwa, NJ: Lawrence Erlbaum.

Taylor, B. (1982). Text structure and children's comprehension and memory for expository material. Journal of Educational Psychology, 74(3), 323 - 340.

Taylor, B., \& Beach, R. (1984). The effects of text structure instruction on middle grade students' comprehension and production of expository text. Reading Research Quarterly, 19(1), 134 - 146.

Vandergrift, L. (1997). The Strategies of second language (French) listeners: A Descriptive Study. Foreign Language Annals, 30(5), 387-409.
Vandergrift, L. (2003). From Prediction Through Refle tion: Guiding Students: Through the Process of L2 Listening. Canadian Modern Language Review, 59(3), 425-440.

Vandergrift, L. (2007). Recent developments in second and foreign language listening comprehension research. Language Teaching, 40(1), 191-210.

Vandergrift, L., \& Tafaghodtari, M. H. (2010). Teaching L2 Learners How to Listen Does Make a Difference: An Empirical Study. Language Learning 60(2), 470-497.

Wei, M. (2007). An examination of vocabulary learning of college-level learners of English in China. Asian EFL J., 9(2), 93-114.

Zarei, A. A, (2003). Patterns of Iranian Advanced Learners Problem with English Collocations: A focus on Lexical collocations. Iranian Journal of Applied Linguistics, 6(1), 137-169.

Zhao, Y. (1997). The effects of listeners' control of speech rate on second language comprehension. Applied Linguistics, 18(1), 49-68. 